\title{
SCIDOC
}

\author{
International Journal of Dentistry and Oral Science (IJDOS) \\ ISSN: 2377-8075
}

\section{Teaching Slow Learners and Fast Learners Sepreatly In Small Group Teaching In Dental School-Students Perception, Concern and Impact}

Research Article

Sheeja S Varghese $e^{*}$, Noorul Aneesa ${ }^{2}$

${ }^{1}$ Professor \& Dean Department of Periodontics Saveetha Dental College, Saveetha Institute of Medical and Technical sciences Saveetha University, Chennai, India.

${ }^{2}$ Undergraduate student Saveetha Dental College, Saveetha Institute of medical and technical sciences Saveetha University, Chennai, India.

\section{Abstract}

Background: Small group teaching is appreciated but separating students in to slow and fast learners based on their academic performances has not been studied in detail.

Aim: The aim of the study was to evaluate the students perceptions and concerns as well as the impact of separate classes for slow learners and fast learners and also to find whether there is any significant differences between slow learners and fast learners' opinion regarding the same.

Materials and Methods: In this study, a questionnaire consisting of 10 questions assessingstudents perception, impact and concern on the separate classes for slow learners and fast learners was prepared and distributed to 150 students of a dental school where small group teaching as well separate classes for slow learners and fast learners are conducted. The data was collected and analysed statistically.

Result: On analysing the data, it was found that a majority of the students $(67 \%)$ rated the concept of small group teaching as an excellent method. However, separate classes for slow learners and fast learners were not well appreciated by the students. More fast learners felt that it affected the unity of the students than the slow learners. A majority of fast learners felt that grouping them based on their performance has improved their classroom learning and improved their confidence in participating in active learning methods where as a majority of the slow learners disagreed.

Conclusion: It can be concluded that small group teaching is preferred by the dental students but separation based on academic performances is not favoured.

Keywords: Separate Classes; Slow Learners; Fast Learners; Small Group Teaching; Dental Education.

\section{Introduction}

Education plays an important role in the development of the country. Countries worldwide believe that their growth and advancement rely on their education systems and traditional teaching methods cannot provide them with the development and transformation they seek [1]. An improvement in the academic achievements of students is one of the main goals of education and teachers can play an important and effective role in this by selecting proper teaching methods [2]. Traditional methods con- sider classrooms as places where the role of teachers is merely to provide information to their students. Students often compete with one another to increase their knowledge. Goals are more personal in such classes which contradict with cooperative classes. Cooperative learning is an educational method in which students cooperatively work towards achieving common goals. Teaching involves primarily transmission of knowledge, but it is also much more than that wherein the students need to be equipped with the social skills [3]. Cooperative learning promotes effective team work and interpersonal skills and at the same time it is more effective than competitive learning for promoting positive learning

*Corresponding Author:

Sheeja S Varghese,

Professor \& Dean Department of Periodontics Saveetha Dental College, Saveetha Institute of Medical and Technical sciences Saveetha University, Chennai, India. Tel: 9884042252

Email Id: sheejavarghese@saveetha.com

Received: March 05, 2021

Accepted: March 12, 2021

Published: March 17, 2021

Citation: Sheeja S Varghese, Noorul Aneesa. Teaching Slow Learners and Fast Learners Sepreatly In Small Group Teaching In Dental School-Students Perception, Concern and Impact. Int J Dentistry Oral Sci. 2021;08(03):2025-2030. doi: http://dx.doi.org/10.19070/2377-8075-21000398

Copyright: Sheeja S Varghese ${ }^{\circ} 2021$. This is an open-access article distributed under the terms of the Creative Commons Attribution License, which permits unrestricted use, distribution and reproduction in any medium, provided the original author and source are credited. 
outcomes [4].

Small-group teaching and learning has achieved an admirable position in medical education and is well-liked as a means of enhancing the process of deep learning. Small group learning is defined as a process of learning that takes place when students work together in groups $[5,6]$. Small group teaching and learning sessions increase student interest, retention of knowledge, enhance transfer of concepts to novel issues, students' critical skills, teamwork ability, self-directed learning, communication skills, student-faculty and peer-peer interaction [7, 8]. The most important characteristics of small group teaching are the active involvement of learners in the entire learning cycle, well defined task orientation with achievable specific aims and objectives in a given time and the reflection based on the experience and deep learning [9]. Small group teaching has many advantages to offer to the learner. These include self direction and active learning. Small group teaching also encourages reflection upon and control of learning activities and development of self-regulatory skills con- ducive to lifelong learning. It facilitates an adult style of learning and the acceptance of personal responsibility for own progress. It promotes transferable skills such as leadership, teamwork, organisation, prioritisation, and encouragement to others, problem solving, and time management skills [10].

Slow learner is a term or concept riddled by educational psychological interpretations. The term slow learner is used to describe a student who takes longer to grasp ideas in the classroom. The concept of slow learning is literal adjunctive statements reflecting examples of individuals failing to consolidate appropriate information in certain contexts [11]. They might have difficulty in doing multifaceted or complex problems and have difficulty in time management. Fast learners are students who have a higher capacity of grasping power and higher speed of learning when compared to slow learners. They take minimal time to understand a particular topic than the slow learners.

In small group teaching which encourages active and cooperative

Table 1. Overall responses of the students for various questions.

\begin{tabular}{|c|c|c|}
\hline Variable & Options & $\begin{array}{c}\% \text { of students who gave } \\
\text { various responses }\end{array}$ \\
\hline \multirow{3}{*}{$\begin{array}{l}\text { Q1. How do you rate the concept of small group } \\
\text { teaching? }\end{array}$} & A. Excellent & $67 \%$ \\
\hline & B.good & $23 \%$ \\
\hline & C. average & $10 \%$ \\
\hline \multirow{3}{*}{$\begin{array}{l}\text { Q2. What is your opinion about grouping students } \\
\text { according to their performance in this small group- } \\
\text { ing? }\end{array}$} & A. agree & $38 \%$ \\
\hline & B.disagree & $48 \%$ \\
\hline & C. no opinion & $14 \%$ \\
\hline \multirow{3}{*}{$\begin{array}{l}\text { Q3. Separate classes for Fast learners and slow } \\
\text { learners is better for both the groups? }\end{array}$} & A. agree & $35 \%$ \\
\hline & B.disagree & $45 \%$ \\
\hline & C. no opinion & $20 \%$ \\
\hline \multirow{3}{*}{$\begin{array}{l}\text { Q4.Separate classes for Slow learners and Fast } \\
\text { learners in small groups is good for more interac- } \\
\text { tive learning? }\end{array}$} & A. agree & $41 \%$ \\
\hline & B.disagree & $41 \%$ \\
\hline & C. no opinion & $18 \%$ \\
\hline \multirow{3}{*}{$\begin{array}{l}\text { Q.5Separate classes for slow learners and fast learn- } \\
\text { ers are really helping the teacher to guide and teach } \\
\text { the students more efficiently? }\end{array}$} & A. agree & $47 \%$ \\
\hline & B.disagree & $33 \%$ \\
\hline & C. no opinion & $20 \%$ \\
\hline \multirow{3}{*}{$\begin{array}{l}\text { Q.6 Grouping students on their academic perfor- } \\
\text { mance is? }\end{array}$} & A. encouragement to students & $33 \%$ \\
\hline & B. discouragement to students & $60 \%$ \\
\hline & C. no opinion & $7 \%$ \\
\hline \multirow{3}{*}{$\begin{array}{l}\text { Q7. Separate classes for slow learners and fast } \\
\text { learners can affect the unity of the students? }\end{array}$} & A. agree & $57 \%$ \\
\hline & B.disagree & $27 \%$ \\
\hline & C. no opinion & $16 \%$ \\
\hline \multirow{3}{*}{$\begin{array}{l}\text { Q8. This system can cause development of superi- } \\
\text { ority complex/ inferiority complex in student }\end{array}$} & A. agree & $17 \%$ \\
\hline & B.disagree & $71 \%$ \\
\hline & C. no opinion & $12 \%$ \\
\hline \multirow{3}{*}{$\begin{array}{c}\text { Q9. Based on my experience I feel that this type } \\
\text { of separate classes has improved in my class room } \\
\text { learning }\end{array}$} & A. agree & $41 \%$ \\
\hline & B.disagree & $47 \%$ \\
\hline & C. no opinion & $12 \%$ \\
\hline \multirow{3}{*}{$\begin{array}{l}\text { Q10. Because of the system I feel that it's been } \\
\text { more confident in participating in active learning } \\
\text { method? }\end{array}$} & A. agree & $43 \%$ \\
\hline & B.disagree & $27 \%$ \\
\hline & C. no opinion & $20 \%$ \\
\hline
\end{tabular}


learning, the grouping of students also matters. It has been reported that the needs of the slow learners can be focussed when they are grouped together and taught separately [12]. At the same time, it is debatable whether grouping the students based on their academic calibre could affect their perceptions of themselves and thereby impact their learning.

In a dental school in South India where small group teaching is practiced, undergraduate dental students of each year (100 students) are divided in to 6 small groups and posted in 6 comprehensive clinics where the clinical training as well as the theory is taught exclusively for each group. The grouping of the students is done based on their academic performances in such a way that high performers and low performers are separated. The aim of this study was to evaluate the students' perceptions and concerns on grouping as well as the impact of grouping based on academic performances and taking separate classes for fast learners and slow learners. The study also aimed to compare the opinions between the fast learners and the slow learners regarding the same.

\section{Materials and Method}

This cross sectional survey was conducted in a dental school in South India where small group teaching is practiced. A questionnaire was prepared consisting of 10 questions (table 1) and was distributed to 150 final year and Compulsory Rotational Interns (CRI) students who were divided into 6 groups and posted in 6 different undergraduate comprehensive clinics. The study was approved by the scientific review board of Saveetha Dental College. The age group of the participants was between 21-23. Both males and females were included in the study. All the students had 1.5yrs-2yrs of small group learning experience where in the grouping was done based on their academic performance. Each group had 16-18 students and among the six groups the first four groups were considered as the fast learners (high performers) of the batch and the last 2 groups were considered as the slow learners (low performers) in their respective batches (final year and CRI batch). The questions were aimed to assess their feedback on small group teaching as well as the grouping being done based on their previous year academic performance. The results were tabulated and descriptive statistics was done and comparison of opinions of slow learners (last two groups) and fast learner (first four groups) was done by Pearson and chi-square test using SPSS software with $\mathrm{p}$ value less than 0.05 considered as statistically significant.

\section{Results}

Overall responses for the questions regarding small group teaching and separate classes for slow learners and fast learners is shown in Table no $1.67 \%$ of the students rated the concept of small group teaching as an excellent method. However, only $(38 \%)$ of the respondents agreed to grouping students based on their academic performance whereas (48\%) disagreed to the same. $45 \%$ of the students believed that separate classes are not better for both slow and fast learners. For the question regarding whether separate classes for slow learners and fast learners is good for more interactive learning, equal proportion of students (41\% each) agreed and disagreed. A majority of the students $(47 \%)$ agreed that separate classes for slow learners and fast learners really help the teachers guide and teach efficiently. $60 \%$ of the respondents believed that grouping students based on academic performance acts as a discouragement to them. A majority of the students $(57 \%)$ felt that grouping students based on their performance would affect the unity among them. When asked if separate classes for slow learners and fast learner would create a superiority or inferiority complex, a majority of the students $(71 \%)$ disagreed. When asked if separate classes help students in improving classroom learning (47\%) students disagreed and (41\%) agreed. A majority of the students (43\%) believed that they had become more confident and could participate better in active learning because of the system.

The statistical comparison of the responses between slow learners (low performers of the batch)and fast learners (high performers of the batch) are given in the Table no 2.

While comparing the opinion regarding small group teaching there was no significant difference $(\mathrm{P}=0.413)$ between the groups i.e. both the groups favoured small group teaching. Also there was no significant difference $(\mathrm{P}=0.58)$ between the groups regarding their opinion on grouping them based on their academic performance. There was a significant difference $(\mathrm{P}=0.024)$ in the opinion on whether separate classes are beneficial for slow learners and fast learners. For the question regarding whether conducting separate classes is good for more interactive learning, there was no significant difference $(\mathrm{P}=0.482)$ in the opinion between slow learners and fast learners. But for the question on whether separate classes helped the teachers guide and teach efficiently, there was a highly significant difference $(\mathrm{P}=0.001)$ in their opinion wherein fast learners agreed for the statement where as the slow learners disagreed.

For the question regarding whether grouping of students based on their academic performances is an encouragement or discouragement, both the groups felt it was discouraging and there was no statistically significant difference in their opinion $(\mathrm{P}=0.143)$. There was a significant difference $(\mathrm{P}=0.011)$ in opinion on whether separate classes can affect the unity of the student where in fast learners were more concerned that it affects their unity. There was a highly significant difference $(\mathrm{P}=0.001)$ in opinions about the development of superiority or inferiority complex by dividing them based on their performance. Majority of the fast learners felt that it can cause development of superiority or inferiority complex whereas slow learners disagreed. Upon analysis of the responses to the last two questions which were intended to assess the impact of the system, there was significant difference between fast learners and slow learners $(\mathrm{P}=0.015, \mathrm{P}=0.005)$. Majority of the fast learners felt that grouping them based on their performance has improved their classroom learning and improved their confidence in participating in active learning methods whereas a majority of the slow learners disagreed to the same.

\section{Discussion}

The present study evaluated the student's perceptions and concerns as well as the impact of separate classes for slow learners and fast learners in a dental school. On analysing the result it was found that most participants believed that small group teaching was an excellent method. Small group teaching is appreciated in various institutions including medical schools, as it provides a productive academic environment. It also involves active partici- 
Table 2. Statistical comparison or fast learners and slow learners with respect to their responses againt various questions(by pearson chi-square test).

\begin{tabular}{|c|c|c|c|c|}
\hline \multirow[b]{2}{*}{ Variable } & \multirow[b]{2}{*}{ Options } & \multicolumn{2}{|c|}{$\begin{array}{l}\% \text { of students who gave } \\
\text { various responses }\end{array}$} & \multirow[b]{2}{*}{ P Value } \\
\hline & & $\begin{array}{l}\text { Fast Learn- } \\
\text { ers }\end{array}$ & $\begin{array}{l}\text { Slow Learn- } \\
\text { ers }\end{array}$ & \\
\hline \multirow{3}{*}{$\begin{array}{l}\text { Q1. How do you rate the concept of small } \\
\text { group teaching? }\end{array}$} & A. Excellent & $88.60 \%$ & $83.3 \%$ & \multirow{3}{*}{0.413} \\
\hline & B.good & $8.6 \%$ & $16.7 \%$ & \\
\hline & C. average & $2.9 \%$ & $0.0 \%$ & \\
\hline \multirow{3}{*}{$\begin{array}{l}\text { Q2. What is your opinion about grouping } \\
\text { students according to their performance in this } \\
\text { small grouping? }\end{array}$} & A. agree & $51.4 \%$ & $23.3 \%$ & \multirow{3}{*}{0.058} \\
\hline & B.disagree & $34.3 \%$ & $6 \%$ & \\
\hline & C. no opinion & $14.3 \%$ & $16.7 \%$ & \\
\hline \multirow{3}{*}{$\begin{array}{l}\text { Q3. Separate classes for Fast learners and slow } \\
\text { learners is better for both the groups? }\end{array}$} & A. agree & $42.9 \%$ & $13.3 \%$ & \multirow{3}{*}{$0.024^{*}$} \\
\hline & B.disagree & $45.7 \%$ & $76.7 \%$ & \\
\hline & C. no opinion & $11.4 \%$ & $10.0 \%$ & \\
\hline \multirow{3}{*}{$\begin{array}{l}\text { Q4. Separate classes for Slow learners and Fast } \\
\text { learners in small groups is good for more inter- } \\
\text { active learning? }\end{array}$} & A. agree & $40.0 \%$ & $26.7 \%$ & \multirow{3}{*}{0.482} \\
\hline & B.disagree & $54.3 \%$ & $63.3 \%$ & \\
\hline & C. no opinion & $5.7 \%$ & $10.0 \%$ & \\
\hline \multirow{3}{*}{$\begin{array}{l}\text { Q.5 Separate classes for slow learners and fast } \\
\text { learners are really helping the teacher to guide } \\
\text { and teach the students more efficiently? }\end{array}$} & A. agree & $62.9 \%$ & $16.7 \%$ & \multirow{3}{*}{$0.001^{* *}$} \\
\hline & B.disagree & $28.6 \%$ & $66.7 \%$ & \\
\hline & C. no opinion & $8.6 \%$ & $16.7 \%$ & \\
\hline \multirow{3}{*}{$\begin{array}{l}\text { Q.6 Grouping students on their academic per- } \\
\text { formance is? }\end{array}$} & $\begin{array}{l}\text { A. encouragement } \\
\text { tpo students }\end{array}$ & $28.6 \%$ & $26.7 \%$ & \multirow{3}{*}{0.143} \\
\hline & $\begin{array}{l}\text { B. discouragement } \\
\text { to students }\end{array}$ & $60.0 \%$ & $73.3 \%$ & \\
\hline & C. no opinion & $11.4 \%$ & $0.0 \%$ & \\
\hline \multirow{3}{*}{$\begin{array}{l}\text { Q7. Separate classes for slow learners and fast } \\
\text { learners can affect the unity of the students? }\end{array}$} & A. agree & $71.4 \%$ & $50 \%$ & \multirow{3}{*}{$0.011^{* *}$} \\
\hline & B.disagree & $14.3 \%$ & $46.7 \%$ & \\
\hline & C. no opinion & $2.9 \%$ & $3.3 \%$ & \\
\hline \multirow{3}{*}{$\begin{array}{c}\text { Q8. This system can cause development of } \\
\text { superiority complex/ inferiority complex in } \\
\text { student }\end{array}$} & A. agree & $80.0 \%$ & $36.7 \%$ & \multirow{3}{*}{$0.001^{* *}$} \\
\hline & B.disagree & $14.3 \%$ & $60 \%$ & \\
\hline & C. no opinion & $5.7 \%$ & $3.3 \%$ & \\
\hline \multirow{3}{*}{$\begin{array}{c}\text { Q9. Based on my experience I feel that this type } \\
\text { of separate classes has improved in my class } \\
\text { room learning }\end{array}$} & A. agree & $65.7 \%$ & $30.0 \%$ & \multirow{3}{*}{$0.015^{* *}$} \\
\hline & B.disagree & $31.4 \%$ & $66.7 \%$ & \\
\hline & C. no opinion & $2.9 \%$ & $3.3 \%$ & \\
\hline \multirow{3}{*}{$\begin{array}{l}\text { Q10. Because of the system I feel that it's been } \\
\text { more confident in participating in active learn- } \\
\text { ing method? }\end{array}$} & A. agree & $80.0 \%$ & $33.3 \%$ & \multirow{3}{*}{$0.005^{* *}$} \\
\hline & B.disagree & $11.4 \%$ & $63.3 \%$ & \\
\hline & C. no opinion & $8.6 \%$ & $3.3 \%$ & \\
\hline
\end{tabular}

"HIGHLY SIGNIFICANT P<0.01.

SIGNIFICANT $0.01<\mathrm{p}>0.050$

pation of students and improves their team work ability. It has been reported that it enhances the student-faculty and peer to peer interactions and communication skills [11].

In the present study, even though a majority of the students had a good opinion on small group teaching, grouping them according to their performance was not very well received. Nearly half of the students agreed that separate classes for slow learners and fast learners was good for interactive learning. A majority of the students reported that separate classes helped the teachers to guide and teach efficiently. Small group teaching demands self motivation, active learning and proper time management. In the case of fast learners and slow learners these capacities might differ. A teacher could facilitate effective teaching in a homogenous group of students who are all of the same caliber. This could be the probable reason as to why a majority of the respondents felt that teacher student interaction was better in our survey. Many respondents felt that grouping students according to their performance is discouraging as it might affect the unity among them. However, it is interesting to note that it was the fast learners 
who felt that such grouping could foster feelings of superiority and inferiority between members of different groups. The slow learners did not have such feelings. Even though more students agreed that the system helped in improving their confidence in participating in active learning, the majority did not agree that it improved their classroom learning. According to Pololi, Frankel, Richard et al small group teaching had a positive influence on the medical students The primary purpose is to develop discussion skills and thinking. Evidence indicated that small group learning sessions are better than large groups at promoting thought and developing attitudes and values [13]. Supporting our result, Adam M Persky and McLaughlin also reported that small group teaching resulted in better academic grades [14]. According to Gopinath, the different teaching methods and video based learning did not have any significant difference in learning outcomes [15].

In the present study we also compared the responses between fast learners and slow learners. While comparing the result statistically, there was a significant difference between most of their opinions. There was no significant difference in their opinion regarding the small group teaching method wherein both the slow learners and fast learners believed it to be an excellent method. But there was a significant difference in their opinion on grouping them based on their performance and whether such grouping helped both the groups. A majority of the fast learners felt that it helped whereas slow learners disagreed to the same. Most of the fast learners agreed that separate classes would help the teacher guide and teach more efficiently while the slow learners disagreed. Similar to our result, a study done by Kulik and Chen in school children reported that homogenous grouping of students was beneficial for the talented students and had very little effect on the average students [16]. In the study, we found that more fast learners were concerned about the system affecting their unity than the slow learners. Similarly, a majority of the fast learners believed that such a system could create feelings of superiority and inferiority among the students while the slow learners disagreed. A majority of the fast learners felt that this system improved classroom learning and boosted their confidence allowing them to perform well in active learning while slow learners did not feel the same.

There are many theories regarding adult learning. Experiential learning theory has influenced adult education by making educators responsible for creating, facilitating and organising experiences in order to facilitate learning. Where as self directed learning suggests that adults can plan, conduct and evaluate their own learning. In the present study the participants were final years and CRRI of age group ranging from 21-23 who fall under adult learners. A small group teaching method which demands active learning will be best suited for this category. Supporting this concept the result of the present study also shows that a majority of the students favoured small group teaching.

There are different opinions regarding separate classes for slow learners and fast learners. Some authors felt that it is better to mix fast and slow learners in one class rather than separating them. It is challenging for a teacher to satisfy both slow and fast learners at the same time in a mixed crowd. Our study also supports that separating them facilitates better teacher-student interaction and learning. The result of the present study highlights one of the major concerns regarding this system i.e. it might affect the unity among the students.
In the present study, even though a majority appreciated small group teaching, dividing students according to their performances as fast learners and slow learners was not very well appreciated. The probable reason for this could be since the study was conducted in a professional college where most of the students are of good learning capacity as their admission itself demands a level of academic proficiency. When these students were divided based on previous years academic performance, the academic calibre of the first and the last group might not be significantly different. The student's perceptions of their educational environment have been studied at all the levels of educational systems [17]. Learning environment has a significant role in determining a student's academic achievement and learning [18]. The group learning encompasses the culture of a school or class and its presiding ethos and characteristics, including how students interact with and treat one another, as well as the ways in which teachers may organise an educational setting to facilitate learning [11]. Studies have shown that the educational environment affects students' achievement, happiness, motivation, and success [19]. The present study emphasises that even in professional courses small group teaching is well appreciated.

\section{Conclusion}

It can be concluded that small group teaching is preferred by the dental students but separating them based on academic performances was not favoured. It is also found that there was a significant difference in the opinion between fast learners and slow learners where fast learners preferred to have separate classes. The study gives an overall opinion about small group teaching and division based on academic performances. Since this was only a cross sectional survey, the analysis was restricted to participants' opinion but not on the actual academic performance or grades. Further studies are needed to evaluate the benefits of small group teaching and separate classes for slow learners and fast learners.

\section{References}

[1]. Mohagheghian S, Ahmadian G, Saadatmand Z. Recognition and application of new teaching models among the humanities faculty members. 2013;

[2]. Angom S. Role of teachers in academic reforms for quality higher education [Internet]. Higher Education and Professional Ethics. 2018;27-44.

[3]. Hensley M, Pratt D. Tools for Teaching Social Skills in Schools: Lesson Plans, Activities, and Blended Teaching Techniques to Help Your Students Succeed. Boys Town Press; 2005. 293 p.

[4]. Prince M. Does active learning work? A review of the research. J Eng Educ. $2004 \mathrm{Jul} ; 93(3): 223-31$.

[5]. Coulehan J, Williams PC. Vanquishing virtue: the impact of medical education. Acad Med. 2001 Jun;76(6):598-605.

[6]. O'Neill G. Small group including tutorials and large group teaching. Centre for Teaching and Learning, Good Practice in Teaching and Learning, UCDDublin. 2003;1-12.

[7]. Jones RW. Learning and teaching in small groups: characteristics, benefits, problems and approaches. Anaesth Intensive Care. 2007 Aug;35(4):587-92. PubmedPMID: 18020080.

[8]. Varghese SS, Ramesh A, Veeraiyan DN. Blended module-based teaching in biostatistics and research methodology: A retrospective study with postgraduate dental students. J Dent Educ. 2019 Apr;83(4):445-50.PubmedPMID: 30745352.

[9]. Meo SA. Basic steps in establishing effective small group teaching sessions in medical schools. Pak J Med Sci Q. 2013 Jul;29(4):1071-6.PubmedPMID: 24353692.

[10]. Steinert Y. Student perceptions of effective small group teaching. Med Educ. 2004 Mar;38(3):286-93.PubmedPMID: 14996338.

[11]. Borah RR. Slow learners: Role of teachers and guardians in honing their hidden skills. International Journal of Educational Planning \& Administration. 2013;3(2):139-43. 
[12]. Cooter KS, Cooter RB Jr. One size doesn't fit all: Slow learners in the reading classroom. Newark. 2004 Apr;57(7):680-4.

[13]. Veerapen K, McAleer S. Students' perception of the learning environment in a distributed medical programme. Med Educ Online [Internet]. 2010 Sep 24;15.

[14]. Persky AM, McLaughlin JE. The Flipped Classroom - From Theory to Practice in Health Professional Education. Am J Pharm Educ. 2017 Aug;81(6):118. Pubmed PMID: 28970619.

[15]. Gopinath V, Nallaswamy D. A systematic review on the most effective method of teaching dentistry to dental students compared to video based learning. American J Educ Res. 2017;5(1):63-8.

[16]. Kulik C-LC, Kulik JA. Effects of Ability Grouping on Secondary School Students: A Meta-analysis of Evaluation Findings. Am Educ Res J. 1982 Jan
1;19(3):415-28.

[17]. Branch Jr WT. Small-group teaching emphasizing reflection can positively influence medical students' values. Academic Medicine. 2001 Dec $1 ; 76(12): 1171-2$.

[18]. Thomas BS, Abraham RR, Alexander M, Ramnarayan K. Students' perceptions regarding educational environment in an Indian dental school. Med Teach. 2009 May;31(5):e185-6.

[19]. Khan JS, Tabasum S, Yousafzai UK. Determination of medical education environment in Punjab private and public medical colleges affiliated with University of Health Sciences, Lahore-Pakistan. J Ayub Med Coll Abbottabad. 2009 Oct;21(4):162-70. 